\title{
A REAL THREAT FROM WITHIN: Muhammadiyah's Identity Metamorphosis and the Dilemma of Democracy
}

\author{
Suaidi Asyari \\ IAIN Sulthan Thaha Saifuddin - Jambi
}

\begin{abstract}
This paper will look at Muhammadiyah as a constantly metamorphosing organism from which have grown modernist-reformist, liberalist progressive, political pragmatist and potentially violent fundamentalist-radical Muslims. It will argue that the trajectory passed by and the victory of the radical-puritan element in the National Congress 2005 can potentially become an obstacle for Muhammadiyah's involvement in the process of implementing democratic values in Indonesia in the future. To keep watching Muhammadiyah's trajectory is crucially important due to the fact that this organization is one of the powerful forces in the world toward the democratization process. In order to be on the right track of democracy, Muhammadiyah has to be able to cope with its internal disputes over democratic values. Only by means of coping with these internal disputes can this organization ensure its role in propagating and disseminating democratic ideas as well as practices in Indonesia.
\end{abstract}

Keywords: Muhammadiyah, metamorphoses, identity, democracy

\section{Introduction: An Overview of Muhammadiyah}

To date, Muhammadiyah has been plausibly assumed to be a moderate Islamic organization which is in a similar position to Nahdlatul Ulama (NU) and does not have any connections with radical individuals or organizations that could be associated with radical Islamic ideology. This paper will I argue that there are some important 
factors that have been overlooked or ignored in this understanding of Muhammadiyah. With the ideology of promoting the "purest" and the "truest" form of Islam in order to establish the truest possible Islamic society, Muhammadiyah was established in Yogyakarta in 1912 by Ahmad Dahlan. The institutions of Muhammadiyah have copied Christian missionaries in terms of their approach to education, orphanages, health clinics and homes for the needy. This was intentionally designed to balance the efforts of Christian missionaries who were converting local people to Christianity.

As a social-religious organization, Muhammadiyah does not have any structural connections with political parties. However, there has been no important national not religious issue that Muhammadiyah has not responded to. Muhammadiyah's ideology has been very much influenced by Wahabism, Muhammad Abduh, Rahid Ridha and Jamaluddin al-Afghani. The mixture of these influences, together with the local political and religious problems around the time of its establishment, has resulted in a blurred picture of this organization. Muhammadiyah has labeled other Muslims who do not practice the same way as they do as practicing $\mathrm{TBC}^{1}$ (takhayul, bid'ah and churafat). One organization included in this is NU that tolerates the use of local costumes in their dakwah activities. Nakamura asserts that MHD represents a link in the chain of Indonesia's "ongoing Islamization", a thesis that I think needs to be reexamined. ${ }^{2}$

Until recently Muhammadiyah privately controls nearly five thousand (4762) educational institutions in Indonesia, ranging from kindergartens to universities. There are four ways that these institutions are attached to Muhammadiyah. Firstly, all these institutions have signs which officially mark them as belonging to Muhammadiyah. Secondly, the curriculum used draws from Muhammadiyah's ideology and doctrine and is designed by members of Muhammadiyah. Thirdly, all teaching and administration staff are members of Muhammadiyah who own a membership card, without which no one can be involved in a Muhammadiyah institution. Finally, a small percentage of the

\footnotetext{
$1 \mathrm{TBC}$ is also the abbreviation of tuberculosis, a deadly disease that once threatened Indonesians. In that sense MHD thinks that tachayul, bid'ah and churafat can kill the "true" Islam.

2 Misuo Nakamura, The Crescent Arises over the Banyan Tree (Yogyakarta: Gadjah Mada University Press, 1983), p. 2.
} 
annual net income of the institution must be shared with the National Board which in turn distributes the funds to organizations who need support. From this, one can conclude that the relationship between Muhammadiyah and the institutions it controls is structurally and ideologically binding.

Apart from educational institutions, Muhammadiyah also controls 315 hospitals and health clinics, 240 orphanages, 1026 financial institutions including banks, insurance providers and cooperatives and thousands of prayer houses, namely mosques, mushalla, langgar and others. Muhammadiyah builds, expands and refreshes its relationships with Indonesian Muslims through these institutions. In one sense this relationship can build a great deal of social capital to be contributed to democracy.

In running its organization and institutions, Muhammadiyah receives funding from three main sources including: internal donators both regular and incidental, fees charged to those who use the facilities that are provided, and external donors. Externally, Muhammadiyah also receives funds from Middle Eastern and Western countries; however, these external sources do not appear very significant. In the last few years, however, due to restrictions from Western countries, most donations from Middle Eastern countries have been discontinued. A local leader of Muhammadiyah (from the Jambi branch) has expressed concern that the Western campaign against terrorism has had a significant impact on the relationship between his organization and their Middle Eastern supporters, especially donors.

All these institutions play an important role in indoctrinating the teachings of Islam that are practiced by Muhammadiyah. In every institution is built a prayer house for daily prayers where three important religious activities are usually organized; daily and Jum'ah prayers, dakwah and collecting donation or charity (infapor shadaqab) for internal purposes. The dakwah activities are usually performed after each prayer. The Islamic rituals that are practiced by Muhammadiyah are introduced through direct experience and the reasons for performing such rituals are inserted along with the dakwah.

In every dakwah activity the preacher usually opens the sermon by quoting a popular hłdit among Muhammadiyah circles or Salafi or Wahhabi in general. For example, "I warn you of the newly invented matters (in the religion), and every newly invented matter is bid'ah, and every bid'ah is misguidance, and every misguidance is in the Hellfire." 
This is a clear way of identifying that (most of the time if not always) the sermon giver is from Muhammadiyah or modernist in general.

A recent study on democracy in Indonesia (Mujani 2003) reveals that $18 \%$ of devoted Indonesian Muslims (santr) closely associate themselves with Muhammadiyah and $48 \%$ with NU. The most recent estimation of the number of people who associate themselves with Muhammadiyah, referred to as keluarga besar Muhammadyah is around 25 to 30 millions. But registered membership of Muhammadiyah is less than one million. I found no official figures of followers of Muhammadiyah that is reliable. I propose to call them "followers" of Muhammadiyah as they follow a particular method of Islamic practice or come from the particular family, who has been involved in the organization for a long time, but they are not necessarily registered or are members of Muhammadiyah. Referring to them as members of Muhammadiyah can be misleading.

There is a very important difference between the followers and members because only the latter have privileges such as access to leadership positions within the structural bodies of Muhammadiyah. Only those who own a membership card can be appointed to be in the head or chair of Muhammadiyah's institutions. However, the followers of Muhammadiyah play important role in implementing Muhammdiyah's policies and decisions both in political and religious matters. Muhamadiyah's policies, decisions and fatwa $>$ concerning religious matters play a significant role in building a spirit of attachment between Indonesian Muslims who practice a set of Islamic rituals on the one hand and Muhammadiyah as an organization on the other; essentially between cultural and structural Muhammadiyah.

Muhammadiyah's trademark as a modernist-reformist organisation is founded on two explanations. Firstly, Muhammadiyah adopted Western leadership in the organization and the institution. Secondly, Muhammadiyah supports the idea of reforming Islamic understanding so is referred to as reformist. The influence of Wahhabism and Ibn Taimiyya's radical-conservative ideology has been overlooked and has not been seriously taken into account.

\section{Muhammadiyah's Identity Metamorphosis}

The collapse of the New Order Government in 1998 has lead to the tremendous advancement of civil society movements in Indonesia. Religiously based movements are seen as one of the basic foundations of this advancement. From a larger group have emerged new smaller 
segments with particular characters and agendas and included in this larger group is Muhammadiyah (MHD). A number of young progressive intellectuals from MHD have initiated a variety of institutions and individual networks. In terms of discourse, they have manifested in the forms of (a) liberal, (b) radical-puritan, and (c) pragmatic-political elements. I am aware that it is rather arbitrary to simplify the metamorphosis of Muhamadiyah into the three forms since there are also other forms that seem to be growing. However the rough analysis I make does not take into consideration a metamorphosis that is yet to be given an established name. Included in this are the tarekat or sufi and collective dbikr practices that have been joined by certain members or followers of MHD in various regions. ${ }^{3}$ These three forms have expressed themselves through the use of MHD autonomous bodies, NGOs, and individual expressions that appear in newspapers, journals as well as regular events such as Tanwir I have named this process a "metamorphosis" because these ways of expressing ideas have gone far beyond the original character of MHD. ${ }^{4}$

The metamorphosis within Muhammadiyah is one result of dialogue between the radical puritan and the modern-liberal elements which has occurred since the Aceh Congress in 1995. But the potential of both elements have existed within Muhammadiyah since it was established in 1912. It has become more apparent, however, since a growing number of Muhammdiyah scholars have graduated from Western and Middle Eastern universities. Over time there have been changes in the element which dominated MHD. This was a product of particular leadership styles. External factors seemed too have also played a significant role leading up to this metamorphosis.

Changes to the internal dynamics of Muhammadiyah in relation to this metamorphosis began during the $43^{\text {rd }}$ Congress held in Aceh in 1995 with the transformation of Majelis Tarjih Muhammadiyah to become MTPPI (Majelis Tarjib dan Pengembangan Pemikiran Islam, or Majlis Tarjih and Islamic Thought Development). It was also at this congress that Muhammadiyah first elected a Western graduate leader,

\footnotetext{
${ }^{3}$ See Fuad Fachruddin, "Educating For Democracy: Ideas And Practices Of Islamic Civil Society Association In Indonesia," PhD Thesis, University of Pittsburgh, 2005.

${ }^{4}$ See http://www.cnr.berkeley.edu/citybugs/insectBasics/metamorphosis.htm, 02-082005, http://www.iiml.ac.in/research/metamorphosis.html, Journal of Theological Studies and Journal of International Affairs and Journal of Religion in various volumes.
} 
Amien Rais to chair the national board. MTPPI has five main agendas; (1) to encourage Muhammadiyah intellectuals to conduct studies and research on Islam as a practice of tajditand as an anticipation of community development; (2) to issue fatwa $>$ on policies that Muhammadiyah leadership should then implement; (3) to accompany and support the Muhammadiyah leadership in guiding Muhammadiyah members in practicing Islamic teaching; (4) to support the Muhammadiyah leadership in providing and improving the quality of ulama; and (5) to direct the disputes of religious matters in order to make them more maslahat (Ar. literally beneficial).

Following the transformation of Majelis Tarjih to become MTPPI, important developments that had a very significant impact within the grand family of Muhammadiyah took place. In 2000 MTPPI launched one of its first publications, Tafsir Tematik. Alquran tentang Hubungan Sosial antar Umat beragama ${ }^{5}$, which, according to Hilman Latief, was the only tafsir that has been published by Muhammadiyah scholars. There are also a number of publications by Muhammadiyah scholars who discuss similar topics of religious tolerance, pluralism and liberalism. ${ }^{6}$

On October 9 2003, JIMM (Jaringan Intelektual Muda Muhammadiyah, or Muhammadiyah Young Intellectuals Network) was founded. The activists who supported the foundation of JIMM are from the third generation of Muhammadiyah but they are also supported by members of the second generation such as Syafii Maárif, Moeslim Abdurrahman, Amien Abdullah and Abdul Munir Mulkhan. They each have some sort of connection with both the literature and universities of Western countries including USA, Europe and Australia.

As a result of their similar names, JIMM was accused of having the same agenda as $\mathrm{JIL}^{7}$, which is in fact undeniably the case. The activists of JIMM proudly present themselves as part of JIMM, especially through articles that they send to national newspapers, such as Kompas,

\footnotetext{
5 Majlis Tarjih dan Pengembangan Pemikiran Islam, Tafsir Tematik. Alquran tentang Hubungan Sosial antar Umat beragama (Yogyakarta: Pustaka SM, 2000).

${ }^{6}$ Among the works are Amin Abdullah, Dinamika Islam Kultral: Pemetaan Atas Wacana Keislaman Kontemporer (Bandung: Mizan, 2000) and Moeslim Abdurrahman, Mubammadiyah sebagai tenda Kultural (Jakarta: Ideo Press dan Maarif Institute for Culture and Humanity, 2003). Similar subjects also appear in the form of articles or opinion appeared in national and local newspapers, such as Kompas, Media Indonesia and Republika.
}

${ }^{7}$ See http://www.islamlib.com. 
Media Indonesia, the Jakarta Post and Republika ${ }^{8}$ as well as local newspapers such as Suara Merdeka and Jawa Pos. This is in addition to seminars, workshops and other scholarly activities they have organized. The act of representing themselves as activists of JIMM is in line with the usual method of Muhammdiyah which involves lots of self promotion. This is one of the dakwah strategies or mubammadiyahisasi in Indonesia. Thus there is a Muhammadiyah Mosque, Muhammadiyah High School and so on. ${ }^{9}$

Apart from JIMM, the liberal element of Muhammadiyah is also supported by some other non-government organizations (NGOs). However, JIMM's involvement in liberal Islamic discourse has overwhelmed the activities of these NGOs. In mid-2003, prior to the establishment of JIMM, Moeslim Abdurrahman edited Muhammadiyah Sebagai Tenda Kultural (Muhammadiyah as a Cultural Shelter), ${ }^{10}$ a book that has a tremendous impact on the tension between the radicalpuritan leaders and liberal intellectuals. It created a 'big bang' within the grand Muhammadiyah family. This book consists of articles authored by newly-popular intellectuals of Muhammadiyah who bluntly criticize the established approach of Muhammadiyah in their dakwah activities and purification. Most of the authors are still very young, but their ideas are brilliant in terms of their awareness regarding what they should do in confronting the radical-puritan element of Muhammadiyah. In introducing the book, Abdurrahman states

"what has to be regretted by the purification movement (of Muhammadiyah) is not only the 'sins' of its cruel (Indo. ganas) and priori history toward local arts and culture, but the worst is that Muhammadiyah as a tajdid movement has become jumud (Ar. stagnant), because it is not able to reform Islamic awareness which is more substantial and

\footnotetext{
8 It has to be acknowledged, however, that there are many papers appearing in Republika that are written by Muhammadiyah young activists who support the radical element and therefore are against the liberal and tolerant discourse.

${ }^{9}$ But one can hardly find a Masjid NU, SMA NU and so forth. Rather, generally NU simply makes a claim that this mosque or that pesantren is theirs just because the congregation practice the same type of Islamic rituals.

10 Moeslim Abdurrahman (ed.), "Muhammadiyah Sebagai Tenda Kultural". This book addresses three main aims, (one) to criticize the dakwah approach that has been used by Muhammadiyah, (two) to provide dakwah cultural (Cultural proliferation) as an alternative, and (three) which seems to be the ultimate aim is to promote liberalism, pluralism, tolerance and democratic values.
} 
open to comprehend that dakwah is not identical with iman proliferation. Rather, dakwah is in fact every religious work for civilization and humanity." 11

In line with Abdurrahman, Abd Rahim Ghozali concludes:

" $[\mathrm{t}]$ herefore, the Majelis Tarjih of Muhammadiyah is not necessarily ambitious to Islamize everyone, neither to prevent anyone from leaving (murtad) their religion, because every human being has the freedom to choose to believe in God. Muhammadiyah cannot claim to be the single holder of the Absolute Truth...consequently, Muhammadiyah is not the (only) best form of dakwah in Islam."12

In October 2003, JIMM and Ma'arif Institute for Culture and Humanity, chaired by Moeslim Abdurrahman, held a workshop with the theme "Building a Visionary, Open and Critical Intellectual Tradition". Maárif addressed the workshop by saying:

This workshop is the most meaningful and significant intellectual leap in Muhammadiyah's development. Therefore, young men (of Muhammadiyah) have to be fearless to pass through an alternative way and not stagnate. Even though this activity is beyond the mainstream, please feel free to join in because before the end of the day it will take its form and thought."13

Numerous topics were presented at the workshop including, Quránic Hermeneutic and Liberal Theology. At the time of this workshop there were a growing number of organized radical Islamic groups in Indonesia so one can identify who the target of this kind of workshop was, namelly, the radical-puritan Islam, including of Muhammadiyah.

JIMM and the other NOGs I have mentioned here have not been officially registered as autonomous bodies of MHD. The radical puritan's use this as a reason to exclude them from Muhammadiyah. However, the central JIMM's office is located in the same office of MHD headquarters, all JIMM activists are also activists of other autonomous bodies of Muhammadiyah and they have used MHD's name and they themselves have always associated their activists with

\footnotetext{
${ }^{11}$ Moeslim Abdurrahman (ed.), "Muhammadiyah sebagai Tenda Kultural". pp. xi-xvi.

${ }^{12}$ Abd. Rohim Ghazali, "Dari Dogmatis ke Kultural", in Moeslim Abdurrahman (ed.), "Mubammadiyah sebagai Tenda Kultural". p. 7.

${ }^{13}$ Republika, 17 October 2003.
} 
MHD. It was as a response to the development of JIMM that the radical-puritan element becomes more apparent in Muhammadiyah. One element often develops an ideologically argumentative spirit in order to identify itself in relation to the other. In fact, it has always been the mainstream of Muhammadiyah and this is due to its historical background which has been maintained in the official platform.

The origins of the radical element within Muhammadiyah inform much of the organizations ideology. The 'ideology' of amr ma'rufinaby munkar or "commanding right and forbidding wrong" is the implementation of a number of verses (Q3:104; Q3:110; Q9:71) and a Hadith of the Prophet Muhammad: "whoever sees a wrong, and is able to put it right with his hand, let him do so; if he can't, then with his tongue; if he can't, then with his heart, and that it the bare minimum of faith". In another Hadi the Prophet was reported to state "I warn you of the newly invented matters (in the religion), and every newly invented matter is bid'ah, and every bid'ah is misguidance, and every misguidance is in the Hellfire". This last Hadi is always recited by a kha (sermon giver) of Muhammadiyah which is a straightforward implementation of the motto: always go back to the Qur'an and Hadith. Thus Muhammadiyah has the task of purifying Islamic teachings from any innovation or corruption. This is also similar to the ideology of Wahahabism which is associated by many scholars with reformist or modernist movements.

The foundations of Wahhabism were based on the eighteencentury evangelist Muhammad ibn 'Abd al-Wahhab. With his puritanical zeal, 'Abd al-Wahhab sought to purify Islam from innovation and to bring it to its pristine form. Wahhabism propagated that the Qurán and the Hadith of the Prophet Muhammad were the sole source of legitimacy thereby this movement exhibited extreme hostility to classical or traditional products of intellectualism, mysticism and school divisions (madhatb) within Islam. The Wahhabism abandoned the attempt to interpret Islam from historical and contextual standpoint and subsequently regarded most of historical Islam as a corruption of the true and genuine Islam. Wahhabism was very intolerant to long-lasting Islamic practices and considered schools of thought as orthodox, hypocritical, the adoption of which was immediately rendered to be mushrik. Their self-proclamation to be the true and authoritative Islam and thus have the right and responsibility to correct the wrong doings of other Muslims is one of the distinctive 
characters of Wahhabism. The creation of long-lists of mushrik and bid'ah acts of other Muslims is the second. ${ }^{14}$ Since its birth, Wahhabism has not spread under its own banner, in fact even the term Wahhabism is regarded as disparaging by its adherents. Wahhabism has been transformed through it's ideology but not through a name or banner. ${ }^{15}$

At the turn of the eighteenth century, Ibn Saud's family joined forces with the Wahhabi movement and those who rebelled against the Ottoman's in Arabia. Although they were defeated by Egyptian forces in 1818 their ideology remained and continued to spread until the early twentieth century when 'Abd al-'Aziz ibn Sa'u took over power and created Saudi Arabia. Islamic history records that Wahhabi rebellions were very bloody because they indiscriminately slaughtered and terrorized whoever did not join them. It was during these periods that so much traditional Islamic heritage was destroyed. Thanks to calls from traditionalist Islamic movements, such as Nahdlatul Ulama from Indonesia, some of that heritage has been saved.

The Wahhabi creed inspired late nineteenth century reformers, such as Muhammad Abduh, Jamaluddin Al-Afghani and Rashid Rida who gathered under the banner of tajdis Their theological and methodological perspectives were identical to Wahhabism. The term reformist Islam does not mean anti-intellectual. However, this group resists historical Islam, including products of classical Islamic scholars. Salafism or reformist Islam very often used humiliating words against their opponents which may have lead to their followers being aggressive.

As a result of greater freedom which is supported by a democratic paradigm, Wahhabism and the famous late nineteenth century reformers inspired Muslims in many parts of the Islamic world to transform themselves into organized movements. Paradoxically this also includes the physically or verbally violent groups that bear a resemblance to the ideological basis of anti- bid'ab and propagating tajdit Included in the list of bid'ah are any cultural traditions that are celebrated at the same place and time as religious rituals. As a result, there have been many local traditions that have been lost. In Indonesia

\footnotetext{
${ }^{14}$ Khaled Abou el Fadl, "Islam and the Theology of Power: Supremacist Puritanism in contemporary Islam is dismissive of all moral norms or ethical values," www.islamfortoday.com.

15 Ibid.
} 
this tajdidideology has been celebrated by Muhammadiyah since the second decade of twentieth century.

Until a decade ago the aim of establishing a pristine Islam and going back to the Qurán and Hadith was implemented consistently without concern for Indonesian traditionalist Muslims who practiced a mixture of Islam and syncretism. Since the early 1990s, however, national leaders of Muhammadiyah and NU have discouraged their followers from discussing these issues because many of the issues are parts of khilafah. ${ }^{16}$ This campaign has not yet reached the grass roots level.

There was a rapid growth in the liberal element which is indicated by the ability of the devotees to dominate the discourse of liberalization, the growing number of publications and activities as well as the courage of the devotees to address liberal related topics in every event organized by MHD. As a result of this there emerged a strong reaction from the fanatics of the radical-puritan element. The challenge that has to be faced by the radical puritan has driven this new phenomenon. The radical puritan element of Muhammadiyah has used every effort to create confrontation. However, both the liberal and radical elements have used media such as Suara MHD, Tanwir MHD, journals and newspapers that are own by Muslims ${ }^{17}$ who in one way or another have relations with Muhammdiyah.

Since the foundation of Muhammadiyah in 1912, the leaders have been very keen to domesticate the disputes among their leaders. Both political and religious disputes have been kept within their circles. The foundation of JIMM has created a milestone in breaking the taboo within this modernist Islam. Freedom of expression and opinion cannot be hidden any longer.

This situation is different to the challenges faced by the proponents of liberal Islam in other parts of the Muslim world because in

\footnotetext{
${ }^{16}$ During a number of interviews the author conducted in Makassar, Banjarmasin and Jambi, many leaders of Muhammadiyah convincingly asserted that as far as TBC (takhayul, bid'ah and churafat) is concern, none of them can be considered as khilafiyah. All those who practice them deserve to be sent to hell. They quoted the famous hadith of bid'ah "every innovation is bida'ah and every bid'ah is in the hell fire".

17 Such as swaramuslim.net www.eramuslim.com, Sabili, http://www.pesantrenonline.com, www.hayatulislam.net, http://www.ummigroup.co.id/, Republika, and others.
} 
many cases financial factors are not an issue, but in Indonesia it is an issue for their opponents. However, the core ideas of liberalism receive more attention than the financial issues. These two issues can be found in articles which have appeared in Republika, Suara Merdeka, journals as well as pamphlets that belong to the radical element. For the radical puritan element, the fact that NGOs, including JIL (Jaringan Islam Liberal; Liberal Islam Network) and JIMM have received financial support from Western countries, such as Ford Foundation and Asia Foundation, is part of a neo-colonial strategy. These funding agencies are not handing out free gifts. The core agenda of liberalism, including pluralism and tolerance is regarded as aiming to replace Islamic values as opposed to liberating Muslims.

During a closed meeting of PP MHD on July $4^{\text {th }} 2002$, Mustafa Kamal, from Forum Peduli Syariah (Syariáh Care Forum) addressed the following complaint:

If the tolerance and pluralism issues will mean acknowledging that there is "truth" other than Islam, that there is a keselamatan (salvation) other than Islam, that there is keselamatan in the church, that there is keselataman in the synagogue, these all invite us to speak up to PP Muhammadiyah. We are appealing what has happened. While the theology of Christianity is founded in numerous verses of the Qur'an it is the trinity which is as corrupt as what Surah Al-Maidah verse 116, An-Nisa verse 171, AlMaidah verse 72, Al-Taubah 30 are acknowledged by Christians. ${ }^{18}$

It is an intriguing inquiry to ask how the puritan elements of Muhammadiyah can be transformed into violence or into radical groups that can hardly be associated with moderate Islam. There are two ways: one is through individual actions and the other is through totally new groups who have the same foundation and ideology. The followers or leaders of MHD who are not satisfied with certain MHD policies have split into either individual radical actors or a group with a totally different name. Prior to the coming of the reformation era there

\footnotetext{
18 See Hilman Latief in "Post-Puritanisme Muhammadiyah Studi Pergulatan Wacana Keagamaan Kaum Muda Muhammadiyah 1995-2002", Tanwir: Jurnal Pemikiran Agama dan Peradaban, vol. 1. No. 2 (July 2003), PSAP Muhammadiyah, Jakarta, pp. 64-65. Compare this complaint to the 11 fatwa of MUI 2005.
} 
were two influential figures in the history of Indonesia in its relations to my arguments, Kahar Muzakkar and Ir. H.M. Sanusi.

Kahar Muzakkar was educated in MHD schools in South Sulawesi and Solo, Central Java. He was an active member of MHD Hiz̧bul Wathan sometime before he was involved in the Darul Islam (DI) rebellion in 1952. According to Martin van Bruinessen, other members of Darul Islam also had modernist backgrounds. ${ }^{19}$ Sanusi was one of the Vice Chairpersons of MHD in 1984, the Minister of Industry in the New Order Government (1966-1968), and one of the founders of HMI (Islamic Student Association). He was involved in providing funds for the BCA bombing in 1984 and sent to jail for 20 years together with some other members of Petisi $50 .{ }^{20}$ While none of what they did was in the name of Muhammadiyah and Muhammaidyah leaders tend to disassociate their connections, no one can deny that their background was as leaders of Muhammadiyah.

In South Sulawesi and South Kalimantan where I conducted some research, one can find a number of Muhammadiyah leaders who joined organizations that have different platform from Muhammadiyah's, such as Hizbut Tahrir in South Kalimantan and KPPSI in South Sulawesi. Hizbut Tahrir (HT) was established in 1953 by Taqiy al-Din al-Nabhani in Palestine and brought to Indonesia by 'Abd al-Rahman al-Baghdadi, a Muslim activist from Australia. In Indonesia HT was still underground until the fall of the Soeharto government. The freedom to establish any association and express opinion as a result of the reformation has made it possible for HT to be an open

\footnotetext{
${ }^{19}$ See Martin van Bruinessen, "The tariqa Khalwatiyya in South Celebes", in: Harry A. Poeze en Pim Schoorl (eds.), Excursies in Celebes. Een bundel bijdragen bij het afscheid van J. Noorduyn (Leiden: KITLV Uitgeverij, 1991), p. 166. For details account on the Darul Islam rebellion, see Anhar Gonggong, Abdul Kahar Muzakekar: Dari Patriot Hingga Pembrontak (Yogyakarta: Ombak, 2004) and C. van Dijk, Rebellion under the banner of Islam: the Darul Islam in Indonesia (The Hague: M. Njihoff, 1981).

${ }^{20}$ Petisi 50 is a loose association established on 5 May 1984 in Jakarta by 50 members consisting of politicians, army seniors, scholars, musicians and university students. Among the members are Haris Nasution, Ali Sadikin, A.M. Fatwa, Rhoma Irama, H.M. Sanusi and others. Their were concerned by what had done by the New Order regime in violating the 1945 constitution, corruption, and other problems that caused by the mismanagement of the New Order. Two of their main goals are to request the New Order government to do a total correction of what the Old Order government of Soekarno had incorrectly done and to implement the 1945 constitution secara murni dan konsekwen (genuinely and fully committed). .
} 
organization. Hibut Tahrir is a political party, but it did not participate in the last two general elections in Indonesia. The aim of HT is explicit; to re-establish the caliphate system with Islamic law as its constitution.

KPPSI was founded as a result of the Muslim Congress (2000) organized by Muslim scholars of Makassar. The driving force behind the congress was part of the Reformation celebration. Included in the founding fathers of KPPSI were Abdul Aziz Kahhar Muzakkar (a son of Kahhar Muzakkar, the exponent of DI/TII), KH Djamaluddin Amien (the Chairman of Muhammadiyah, South Sulawesi), Alwiyuddin, the Head of Dakwah Division of Muhammadiyah, KH Sanusi Baco (Chairman of NU South Sulawesi), Tamsil Linrung (HMI and PAN) AM Fatwa (PAN) and some other important figures from South Sulawesi. KPPSI has a clear goal which is to implement Islamic Syariáh under a special autonomy of South Sulawesi.

KPPSI has a division called Laskar Jundullah (the Army of God) which was headed by Agus Dwikarna who was once captured in Manilla and accused of carrying explosive materials. KPPSI officially stated that they would stay under the NKRI (the United States of Indonesian Republic) and they will not use violence and they acknowledge the existence of DPR (People Representative Assembly). My survey of various local media has shown that Laskar Jundullah has been involved in a number of violent acts, or at least uses rhetoric that can encourage violence.

After the province of Aceh was declared under Islamic law by Indonesian government in 2001, KPPSI sent a delegation to meet Akbar Tanjung, the Spokesperson of DPR/MPR to request the same status for South Sulawesi. There has been no follow-up whatsoever. In March 2005, KPPSI conducted its third Muslim Congress in Bulukumba South Sulawesi. The congress was officially opened by Hidayat Nur Wahid, the Chairperson of MPR, who was formerly the President of PKS. Since then, KPPSI has not shown any significant development. This quietness might be due to the fact that Jusuf Kalla, who is a member of the Advisory Board of KPPSI, is the current Vice President of the country. Any political issue from South Sulawesi which will potentially have a national impact can jeopardize Kalla's political position. Kalla as the candidate of Vice President of Bambang Susilo Yudoyono gained more than $73 \%$ votes in South Sulawesi. 
In an interview, Djamaluddin Amien, the Chairman of Muhammadiyah South Sulawesi, explained that the decisions of the leaders of Muhammadiyah who joined KPPSI were totally their own individual choices and had nothing to do with Muhammadiyah as an organization. Nasaruddin Razak, the chairman of Muhamadiyah prior to Amien's period agrees with Amien's position. Alwiyuddin reasoned that the only way to implement Islamic law is through KPPSI, because Muhammadiyah does not have the capacity to do so. It is quite difficult to predict whether KPPSI will succeed in their agenda to implement Islamic Law in South Sulawesi, but what is clear is that most leaders of Muhammadiyah support this committee on an individual basis.

The product of several interviews with Muhammadiyah leaders in Makassar is that there is one significant conclusion we can make that the main argument behind Muhammadiyah leaders joining KPPSI is the failure of the Indonesian Constitution in bringing to an end bad morality in Indonesia. According to the existing law the Indonesian government has no power to determine social and religious problems. Government apparatus, including judges, policemen, military and others do not have a strong spirit to encourage good religiously moral deeds and to forbid actions considered bad according to Islam. KPPSI is believed to be able to do this job of amr ma'rufraby munkar.

Leaders of the local Muhammadiyah in South Sulawesi are not confronted by the liberal or progressive element; however, this is apparent at the national level. The clash between the liberal and radical puritan elements has taken a particular form. At the national headquarters of Muhammadiyah rumors spread that there are different schools of thought on the third and fourth floors of the building, mazhab lantai empat and mazhab lantai tiga. ${ }^{21}$ On the fourth floor are the offices of IMM, IRM and Pemuda Muhammadiyah. Those who are activists of these official autonomous bodies of Muhammadiyah are later more famous as activists of JIMM and PSAP. While on the third floor is the office of MTDK (Majlis Tabligh dan Dakwah Khusus, or Council of Tablig and Special Dakwab) whose activists are the radical-puritans. The Council of Tablig sees that the liberal groups have not only

\footnotetext{
21 There was no clear explanation regarding who first introduced the madzhab lantai tiga or madzhab lantai empat and when it was exaclt popularized. One thing is sure that it was a conflict between younger and older leaders of Muhammadiyah since the establishment of JIMM and the publication of the monthly journal of Tabligh.
} 
deviated from the Muhammadiyah tajdidideology but considers that JIMM has also deviated from Islam. It was since the publication of the Tarjih Journal that the clash between the two elements has been institutionally and academically established. In a Tabligh, June 8 2005, Fakhrurrazi Reno Sutan addressed a number of concerns that Muhammadiyah is facing. The most dangerous concern according to Sutan is the existence of liberal elements within Muhammadiyah. He concludes that the Council of Tablig has to be in the forefront to safeguard Muhammadiyah from such a danger.

For most regional leaders of Muhammadiyah in the three provinces where I conducted my fieldwork the establishment of liberal NGOs by young intellectuals of Muhammadiyah, such as JIMM, is a real threat to Muhammadiyah. Adijani al-Alabij, a vice chairman of Muhammadiyah Makasar, for example, argued that the reform idea that Muhammadiyah took from Muhammad Abduh, Rashid Rida and Jamaluddin Al-Afghani had nothing to do with liberalism. The reform that Muhammadiyah has been campaigning for so far is to return to the Qurán and the Hadith of Prophet Muhammad. JIMM is not different from JIL in the sense that both spread liberal virus that endanger Islam, advocate Christian theology, colonialists or Western agent and are slaves to orientalist ideas. For them pluralism has at least three threats: (1) it will create a generation of weak Muslims in terms of how strictly they hold to Islamic teachings, (2) it will create a generation of Muslims who are careless about whether their way of life is in accordance with Islam or not, and most seriously (3) that these two dangers will mean that the struggle to implement Islamic Law will fail.

What I found interesting is these leaders who express such strong resistance to liberal ideas have generally used the media to promote and explain their position. In short, both the radical-puritan and the liberal element have been using what democratic theorists suggest are prerequisites for democracy.22 However, when it comes to the procedural democracy where there is a possibility for the majority to rule, there is a very real threat to those who promote liberal ideas. This is what happened during the national congress that took place in Malang 2005, the radical-puritan element has temporarily won the structural position over the liberal element.

${ }^{22}$ See W.T. Stace, What Are Our V alues?: Values in General, Democratic Values and Why Do We Fail? (Lincoln: The University of Nebraska, 1950). 
The third element is pragmatic-political element. The political party PAN was initiated, founded and firstly chaired by Amien Rais, the Chairman of PP Muhammadiyah 1995-2000. According to their platform PAN is a secular and open political party. Practically and pragmatically, both leaders and followers of Muhammadiyah have been absorbed by PAN at national and local levels. Therefore, politically ambitious youths of Muhammadiyah have turned PAN into an alternative to PPP which used to channel newly born politicians of Muhammadiyah before the era of reformation. ${ }^{23}$

The commitment of PAN to be a secular political party has shown through the recruitment of its office bearers who are not only from Muhammadiyah or are Muslim, but also who are non-Muslim. These office bearers were then given opportunities to be registered on the list of candidates in the legislative for the 1999 and 2004 General elections. The growing number of young politicians from Muhammadiyah on the one hand and the recruitment from outside Muhammadiyah on the other made PAN impossible to provide enough space for young Indonesians from Muhammadiyah to join this party.

After realizing that PAN was not going to provide adequate space for Muhammadiyah cadres, Amien Rais made an effort to show that PAN does not have formal relationships with Muhammadiyah apart from the historical fact that it was founded by him. Many Muhammadiyah cadres at the local level have discouraged Muhammadiyah followers to vote for PAN. Thus their campaign slogan is, "Amien Rais Yes, PAN No". Local cadres have been pragmatically active and have succeeded. In Java, however, the same category of Muhammadiyah cadres took a more strategic approach by calling for a more ideal action which was to establish a new political party for Muhammadiyah.

The discourse of establishing a political party of Muhammadiyah was initially addressed during Mataram Tanwir held in December 2004 during which it was decided that Muhammadiyah youths can take further actions to establish a political party. In December 2004 a team of 12 members, including Abdul Mu'thi (the Chairman of Muhammadiyah Youth), Ahmad Rofiq (Chairman of IMM), Sudar

\footnotetext{
23 There have been a number of works on how politicians of Muhammadiyah have been channeled through particular political parties. For Muhammadiyah and Masyumi, see Saifullah, Gerak Politik Muhammadiyah Dalam Masyumi. (Jakarta : Grafiti, 1997).
} 
Siandes (Chairman of IRM) and the Chairman of Nasyiatul Aisyiyah met at the National Headquarters of Muhammadiyah and agreed to found PAM (Association of Muhammadiyah Mandate). In March 2005, the foundation of PAM was officially declared at the same place. For a temporary period, the political aspirations of certain young politicians of Muhammadiyah were accommodated.

There are several other explanations for the establishment of PAM. It is very clear that historically Muhammadiyah has been resistant to any ideology other than Islam. The fact that PAN is an open political party with secular platform, from which non-Muslim politicians were also recruited, has created a dilemma for Muhammadiyah. Thus for the puritan element of Muhammadiyah, the argument that PAN has not provided enough space for Muhammadiyah politicians hides the theological issues in this discourse. How can the radical puritans of Muhammadiyah support politicians who are not Muslim? In two separate group discussions in the Provincial Headquarters of Muhammadiyah in Banjarmasin and Makassar, all the Muhammadiyah leaders who attended the group interviews agreed that there is a very serious question to be asked on the role of Muhammadiyah politicians in PAN. They questioned why Muhammadiyah politicians are so weak whenever they encountered wrong doings in the respected areas. Even though, they agreed that there are other elements within PAN, but they could not be ensured what these elements are.

Another explanation can be related to the endeavors of PKS (Prosperity and Justice Party) to attract young politicians from Muhammadiyah. PKS's agenda is not very different from what many leaders of Muhammadiyah have been struggling for which is part of "encouraging good and forbidding wrong". However, the exclusive appearance 24 of PKS activists seems to challenge the inclusive appearance of young intellectuals of Muhammadiyah. PKS, formerly PK (Justice Party), was initially founded by Muslim students from secular university campuses, called Tarbiyah Movement, who tried to disregard Muslim divisions based on school of law. Among the prominent figures of the founder were $\mathrm{Abu}$ Ridho and Rahmat Abdullah, both were graduates of al-Azhar University, in Cairo.

\footnotetext{
${ }^{24}$ By inclusive appearance, I mean the way they get dressed, tradition of growing beards, using certain style of hat to cover their heads and as such.
} 
Inspired by Sayyid Qutb's ideas, the activities of these groups (called usroh later known as halaqah) discussed a number of books authored by Qutb under a murabbi or instructor. Under the repressive regime of Soeharto, these groups kept their activities secret or at least not so aggressive in their appearances. The Reformation era has not only provided a way for them to be open to the public, but also became a political party. Because many of national leaders of PKS came from a Muhammadiyah background, certain young politicians of Muhammadiyah were also encouraged to join. Many, however, seem to be reluctant because of the exclusive appearance of PKS politicians.

\section{Malang Congress 2005 and the Victory of Radical-Puritan}

The main factors that make the Malang Congress of Muhammadiyah 2005 significantly important in the Indonesian Islamic and political sphere includes the victory of Dien Syamsuddin, the demolition of the "liberal wing" and the domesticating of the political wing, PAM. One intriguing question is: what kind of scenario was taking place that enabled the situation to result in this reality? This leads to two further questions: which element of Muhammadiyah played a more significant role and why did this element win? Explanations to these questions will help us understand more about the perspective of Muhammaidyah in the future of Indonesia.

One way to answer these questions is through examining the central figure who had been elected to chair the national leadership of Muhammadiyah 2005-2010 and who voted for him. Procedurally speaking, the succession in the Muhammadiyah leadership is very democratic in the sense that every leader who meets the administrative prerequisites is eligible to run in the election. At the first step every leader who wants to run in the election has to complete a form called CPCPM (Catatan Pokok Calon Pemimpin Mubammadiyah or main record of Muhammadiyah leadership candidacy) in which the candidate has to provide information that he needs to support his nomination. Above all, however, is the record of membership without with one will be considered ineligible.

Despite the fact that those who sorted and listed the names of the candidates were from Tanwir where only a limited number of local leaders attended, it is local representatives who played the greatest role in deciding who should be elected. The majority of local representatives elected Dien Syamsuddin among the 204 candidates who met the criteria to lead Muhammadiyah for 2005-2010. According to 
Asnawi Mukti, "in order to safeguard Muhammadiyah from the danger of liberalism, such as JIL and JIMM, only a figure like Syamsuddin was suitable to lead Muhammadiyah." Mukti viewed leaders such as Abdul Munir Mulkhan and Amien Abdullah as liberal in the sense of contradictory to the Muhahmmadiyah ideology of bid'ah and shirk. "How can Muhammadiyah be led by those who acknowledged that all religions are the same?", he apologetically asked. ${ }^{25}$

Syamsuddin is actually not a new figure in the Indonesian Islamic political sphere. He grew up in a devoted family of NU background but jumped into Muhammadiyah circles and became the temporary chairman of IMM (Muhammadiyah Student Association) in 1985. This was the first political maneuver which he continued to be involved in until his latest position. After finishing his PhD at UCLA he became the chairman of the department of Research and Development of Golkar. He was elected as one of the chairmen of Muhammadiyah for the period of 2000-2005 during the National Congress of Muhammadiyah in 2000.

What made Syamsuddin different both from his personal perspective and as a leader of Muhammadiyah was that after he was appointed to be General Secretary of the semi-governmental Council of Indonesian Islamic Scholars (MUI) a number of controversial fatwas (religious edicts) were issued while he was serving this position. This was doubled by his skills as the key spokesperson of MUI. By doing this he under shadowed the Chairman of MUI, K.H. Sahal Mahfud. Under the endorsement of interim President B.J. Habibie, Syamsuddin was appointed to the position of General Secretary of MUI during the $6^{\text {th }}$ National Congress held in 2000. Robert Hefner included Syamsuddin as one of the three most responsible for the outreach of Soeharto to Muslim hardliners. ${ }^{26}$ During Muslim-Christian Maluku conflicts in 2000-2002, Syamsuddin explicitly gave moral support to Islamist paramilitaries battling Christians in the islands of Maluku. He also declared jiha (holy struggle) against the US when George W. Bush attacked Afghanistan after the September 11, 2002.27

\footnotetext{
${ }^{25}$ My personal interview with Asnawi Mukti 28-03-2005 in Jambi.

26 The other two were Soeharto's son-in-law, (then) Major-General Prabowo Subianto and commander of the armed forces, Faisal Tanjung.

27 Robert Hefner, "Globalization, Governance and the Crisis, of Indonesian Islam" presented at Conference on Globalization, State Capacity, and Muslim Self Determi-
} 
During the period Syamsuddin acted as the General Secretary of MUI, MUI became the object of criticisms of the proponents of democratic values, such as pluralism and freedom of religion. There were 11 MUI fatwas announced in the National Congress in July 2005 which were extraordinarly controversial because they gave a sign that this semi-governmental council of ulama has been co-opted by the radical wing of Indonesian Islam. ${ }^{28}$ The 11 fatwas of MUI shocked not only those who were proponents of democracy but also those who are considered to be moderate. The most controversial among the eleven fatwas are: (1) MUI edicts that pluralism, secularism and liberalism are not permissible in Islam; (2) Ahmadiyah ${ }^{29}$ is hframe, (3) prayer together with non-Muslims is horam because it is bid'ab. ${ }^{30}$ In one occasion Syamsuddin addressed his personal views on Ahmadiyah saying that because Ahmadiyah does not believe that the Prophet Muhammad is the last prophet, this sect of Islam has deviated from the mainstream of Islam. Ahmadiyah and JIL have become the target of violence of radical Islam in a number of occasions since.

\section{Conclusion}

The emergence of the three elements from Muhammadiyah is the product of the seeds of democratic values. By using procedural democracy at the National Congress held in July 2005, the liberal progressive and the political pragmatic elements have been excluded from the stage, at least temporarily. The possibility of this process alienating those who promote normative democratic values through procedural democracy is very open. It is not impossible unfortunately in due time all the spaces are securely closed for such progress. In other words, reformist Islam like Muhammadiyah can adopt and use

nation, Center for Global, International, and Regional Studies, University of California-Santa Cruz, March 7-9, 2002.

28 On how the radical or hardliners of Islam have gained position in certain bodies or institutions in Indonesia, see Ibid., pp. 10-12.

${ }^{29}$ On this sect of Islam see Spencer Lavan, The Ahmadiyah Movement: Past and Present (Amritsar: Dept of History, Guru Nanak Dev University, 1976) and for Ahmadiyah in Indonesia see an apologetic of Hamka Haq Al-Badry, Koreksi Total Terhadap Abmadiyah (Jakarta: Yayasan Nurul Islam, 1981).

30 One has to bear in his mind that the use of bidáh as a basis of judging religious matters is more common in the modernist circle, such as Muhamdiyah and Persis than in the traditionalist circle, such as NU. 
procedural democracy but there is a real dilemma when it touches normative democratic values, particularly when it confronts their ideology. There is a real dilemma both in Islam and democracy.

Despite the fact that since the middle of 1995 there have been some developments of Muhammadiyah toward democratic values, two conditions have always become obstacles; firstly, the style of individual leaderships which depends very much on the majority who have the right to vote during its National Congress and secondly, the puritan ideology which was the main force keeping this organization in existence. Muhammadiayh is, therefore, institutionally modern, ideally reformist, but ideologically radical puritan and has potential to be aggressive and violence in any form. Since Muhammadiyah is one of the largest Islamic organizations in the world in almost every dimension, and has the potential to lead it's followers in a direction which may involve violence, to keep updating and evaluating our knowledge about it is a significantly important. []

\section{Bibliography}

\section{Books and Articles}

Abdullah, Amin. Dinamika Islam Kultral: Pemetaan atas Wacana Keislaman Kontemporer. Bandung: Mizan, 2000.

Abdurrahman, Moeslim. Muhammadiyah sebagai Tenda Kultural. Jakarta: Ideo Press dan Maarif Institute for Culture and Humanity, 2003.

Al-Badry, Hamka Haq. Koreksi Total Terhadap Abmadiyah. Jakarta: Yayasan Nurul Islam, 1981.

Dijk, C. Van. Rebellion under the Banner of Islam: the Darul Islam in Indonesia. The Hague: M. Njihoff, 1981.

Fachruddin, Fuad. Educating for Democracy: Ideas and Practices of Islamic Civil Society Association in Indonesia. PhD Thesis. University of Pittsburgh, 2005.

Gonggong, Anhar. Abdul Kabar Muzakekar: Dari Patriot Hingga Pemberontak. Yogyakarta: Ombak, 2004.

Hefner, Robert, W. Globalization, Governance and the Crisis of Indonesian Islam. presented at Conference on Globalization, State Capacity, and Muslim Self Determination, Center for Global, 
International, and Regional Studies. University of CaliforniaSanta Cruz, March 7-9, 2002.

Latief, Hilman. "Post-Puritanisme Muhammadiyah Studi Pergulatan Wacana Keagamaan Kaum Muda Muhammadiyah 1995-2002", Tanwir: Jurnal Pemikiran Agama dan Peradaban, Vol. 1, No. 2, Jakarta: PSAP Muhammadiyah, July 2003.

Lavan, Spencer. the Ahmadiyah Movement: Past and Present. Amritsar: Dept of History, Guru Nanak Dev University, 1976.

Majlis Tarjih dan Pengembangan Pemikiran Islam. Tafsir Tematik Al quran tentang Hubungan Sosial antar Umat Beragama. Yogyakarta: Pustaka SM, 2000.

Nakamura, Misuo. The Crescent Arises Over the Banyan Tree. Yogyakarta: Gadjah Mada University Press, 1983.

Saifullah. Gerak Politik Muhammadiyah dalam Masyumi. Jakarta: Grafiti, 1997.

Stace, W.T. What Are Our Values?: Values in General, Democratic V alues and Why Do We Fail?. Lincoln: The University of Nebraska, 1950.

van Bruinessen, Martin. "The Tariqa Khalwatiyya in South Celebes", in Harry A. Poeze en Pim Schoorl (eds.). Excursies in Celebes. Een bundel bijdragen bij het afscheid van J. Noorduyn. Leiden: KITLV Uitgeverij, 1991.

\section{Electronic Sources}

el Fadl, Khaled Abou. Islam and the Theology of Power: Supremacist Puritanism in Contemporary Islam is Dismissive of all Moral Norms or Ethical Values. http://www.islamfortoday.com.

http://www.cnr.berkeley.edu/citybugs/insectBasics/metamorphosis.htm, [accessed on 02-08-2005).

http://www.iiml.ac.in/research/metamorphosis.html.

http://www.islamlib.com.

http://www.pesantrenonline.com.

http://www.ummigroup.co.id.

http://www.swaramuslim.net.

http://www.eramuslim.com. 
http://www.hayatulislam.net.

Newspapers and Reports

Republika, 17 October 2003. 